\title{
PROPOJENOST P̌̌ÍRODNÍ A HUMÁNNÍ SLOŽKY GEOSFÉRY V HISTORICKÉM VÝVOJI JAKO MOTIVACE K NÁVŠTĚVĚ MORAVSKÉHO KRASU
}

\author{
Petr Chalupa, Ján Veselovský
}

\begin{abstract}
The composite geosphere undergoes a permanent development process. During the genesis, symbiotic interconnection of the two components changes significantly, as demonstrated by the example of the Moravian Karst, where the differences between the dynamics of social economic and social development are manifested and, in comparison with that, the almost invariable development of nature is particularly noticeable. The settlement structure has remained virtually unchanged since the Middle Ages. The interconnection of social development and nature, including thousands of years of human history, can be seen at every step in the Moravian Karst and is a motivating fokert for visitors.
\end{abstract}

Keywords: Moravian karst, attendance, motivation, nature, economy, history, symbiotic interconnectivity

\section{Úvod}

Geosféra složená z fyzickogeografické složky tvořené přírodou a humánní složky, která je výsledkem činnosti člověka, prochází permanentním vývojovým procesem. V průběhu geneze se symbiotická propojenost obou složek významově mění. Toto demonstrujeme na př́íkladu Moravského krasu, kde jsou zvláště patrné a výrazné projevy rozdílu mezi dynamikou společenského, ekonomického a sociálního vývoje ve srovnání s relativně téměř neměnným vývojem př́rody

Chráněná krajinná oblast (dále $\mathrm{CHKO}$ ) Moravský kras je př́rodně unikátní největší krasové území České republiky s více než 1100 jeskyněmi (mapa 1). Má rozlohu $94 \mathrm{~km}^{2}$ a byla vyhlášená v roce 1956 . V některých jsou zachovány nejstarší doklady dávno vyhynulých forem života. Jiné jeskyně zase přinášejí informace o nejstarším lidském osídlení krasové oblasti. Před 120 tisíci roky se neandertálský člověk ukrýval $\mathrm{v}$ jeskyni Kůlna, která má portál o rozměrech $44 \times 8 \mathrm{~m}$ a je $\mathrm{v}$ podstatě tunel dlouhý $87 \mathrm{~m}$, široký $25 \mathrm{~m}$ a vysoký $8 \mathrm{~m}$. V jejich kulturních vrstvách byly objeveny artefakty od neandertálců až po nálezy ze středověku. Zajímavé rytiny od lovců koní, sobů a bizonů z doby před 11 až 13 tisíci roky jsou z jeskyně Pekárna. Ve světě je unikátní nález bronzového býčka je $z$ jeskyně Býčí skála.V minulosti krasové jeskyně nabízely celé spektrum možností využití svých prostor. Proto byla oblast Moravského krasu trvale osídlena již v období pravěku (Ondrušková, 2011). Pro vznik pozdějších sídel, jejichž sídelní struktura se od 
středověku prakticky beze změn udržela do současnosti, se stalo určující působení lokalizačních faktorů. Úplně na opačném konci historie lze v jeskyni Výpustek najít doklady o německé válečné výrobě za druhé světové války a zařizení armády z období studené války a politického vývoje do roku 1989.

Určujícími lokalizační faktory vzniku sídelní struktury a hospodářského zaměření regionu byly, mimo příznivé klimatické podmínky, také dostatečné zásoby železné rudy, stromová skladba přirozených porostů daného výškového stupně a poměrně dobře dostupná vodní energie. To ovlivnilo nejen zemědělskou činnost, ale umožnilo rozvoj řemeslné výroby a později průmyslu, jehož stopy jsou dochovány v četných př́istupných technických památkách.

$Z$ výše uvedeného vyplývá, že region tak má, kromě jedinečných př́rodních zajímavostí a dokladovaných historických památek, obrovský potenciál cestovního ruchu. Nejznámější a nejnavštěvovanější jsou bezesporu veřejnosti prrístupné jeskyně (Punkevní, Kateřinská, Balcarka, Výpustek a Sloupsko-šošůvské) a propast Macocha, kam směřuje drtivá většina návštěvníků.

Není nadnesené, když řekneme, že propojení společenského vývoje a přírody, včetně tisícileté lidské historie, je v Moravském krasu vidět na každém kroku a mělo by být jedním $\mathrm{z}$ hlavních motivů $\mathrm{k}$ návštěvě.

\section{Teoreticko-metodická východiska}

Byla zvolena historicko-geografická metoda, která umožňuje hlubší pochopení propojenosti fyzickogeografické a socioekonomické sféry vjejich vzájemných vztazích a vývoji. Na tuto možnost upozorňuje již v polovině minulého století např̀. Jacunskij (1950). V souladu s Ivaničkou (1971) na základě výběru vhodných událostí v různých historických obdobích dokumentujeme nejen časový přehled o společenských, ekonomických a technologických změnách ve vztahu k proměnám krajiny a lidských sídel, ale také prezentujeme genezi jejich různě silné symbiotické propojenosti. Obdobné problematice, ale bez důrazu na vzájemné vztahy, se věnovalo velké množství autorů. Našemu komplexnímu pojetí se nejvíce svými studiemi přibližili Hübelová, Pavlík (2016), Hübelová, Hořínek, Pavlík (2016), Chalupová (1997) a Pavlík, Konečný, Hübelová (2016).

\section{Pravěk}

Pravěk představuje zhruba období od vzniku vývoje člověka, což bylo někdy na rozhraní třetihor a čtvrtohor, až po zavedení písma někdy kolem roku 4 000 př. n. 1.. Nejstarší periodou pravěku je paleolit - starší doba kamenná - kdy člověk zručný (Homo habilis) začal uživat kamenné nástroje. Perioda trvala až po poslední dobu ledovou v kvartéru. Před 120 až 140 tisíci lety ve starší době kamenné žili na území Moravského krasu lovci medvědů. 
Mapa 1: Moravský kras (www.old.ochranaprirody.cz)

Map 1: Moravian karst (www.old.ochranaprirody.cz)

\author{
KULTURNI PARÁTIXY

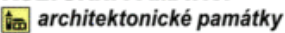 \\ : zríceniny hradú \\ technické památky \\ T) archeologické památky \\ 1. Chrám P. Marie Bolestné \\ 2. Jeskyně Külna \\ 3. Hrad Holštejn \\ 4. Větrný mlýn Ostrov u Macochy \\ 5. Hrad Blansek \\ 6. Vẽtrný mlýn Rudice \\ 7. Hut' Františka \\ 8. Jeskyně Býči skála \\ 9. Chrám Jména P. Marie \\ 10. Jeskynĕ Pekárna \\ 11. Hradisko Chochola
}

(-) PAMATNÉ STROMY

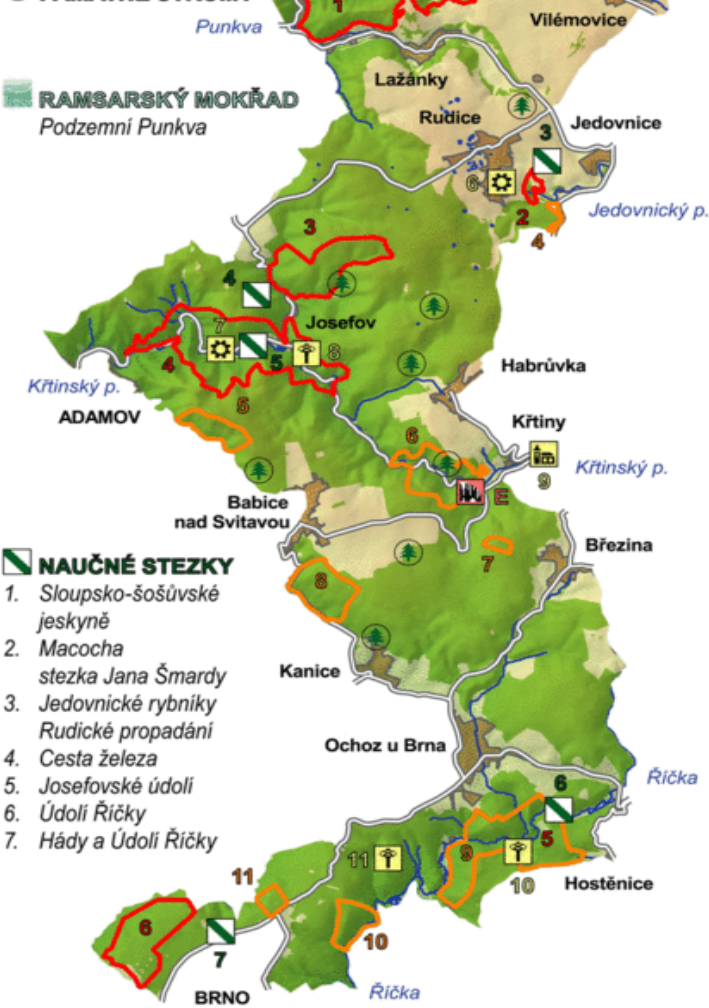

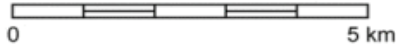

oup
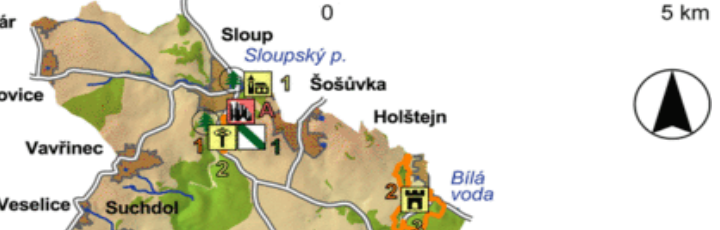

Suchdo

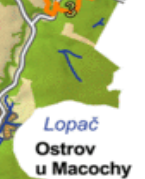

u Macochy

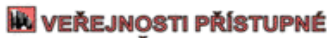
JESKYNNE⿵

A Sloupsko-šošũvské jeskyně

B Jeskyně Balcarka

C Punkevni jeskyně, propast Macocha

D Kateřinská jeskyně

E Výpustek

\section{NARODNI PŘIRODNI REZERVACE (NPR) NARODNI PŔRTODNI} PAMATKY (NPP)

1. NPR Vývěry Punkvy

2. NPP Rudické propadáni

3. NPR Habrùvecká bučina

4. NPR Býči skála

5. NPP Jeskynę Pekárna

6. NPR Hádecká planinka

$\square$ PAIRODAI REZERVACE (PR)

1. PR Sloupsko-šošûvské jeskyně

2. PR Bilá voda

3. PR Balcarova skála - Vintoky

4. PR Mokřad pod Tipečkem

5. PR Drínová

6. PRU Výpustku

7. PR Bíezinka

8. PR Cihadlo

9. PR Údoli Ŕičky

10. PR Velký Hornek

11. PR U Brněnky

Chráněná krajinná oblast MORAVSKÝ KRAS 
Následně po nich osídlili krasové území lovci mamutů. Jeskynní lokality (Pekárna, Býčí jeskyně, Výpustek, Kůlna) je možné vnímat již v pravěku jako součást sídelní struktury krajiny (obr. 1) (Ondrušková, 2011).

Obr. 1: Jeskyně Kůlna u Sloupu

Figure 1: Cave Kůlna at the Sloup

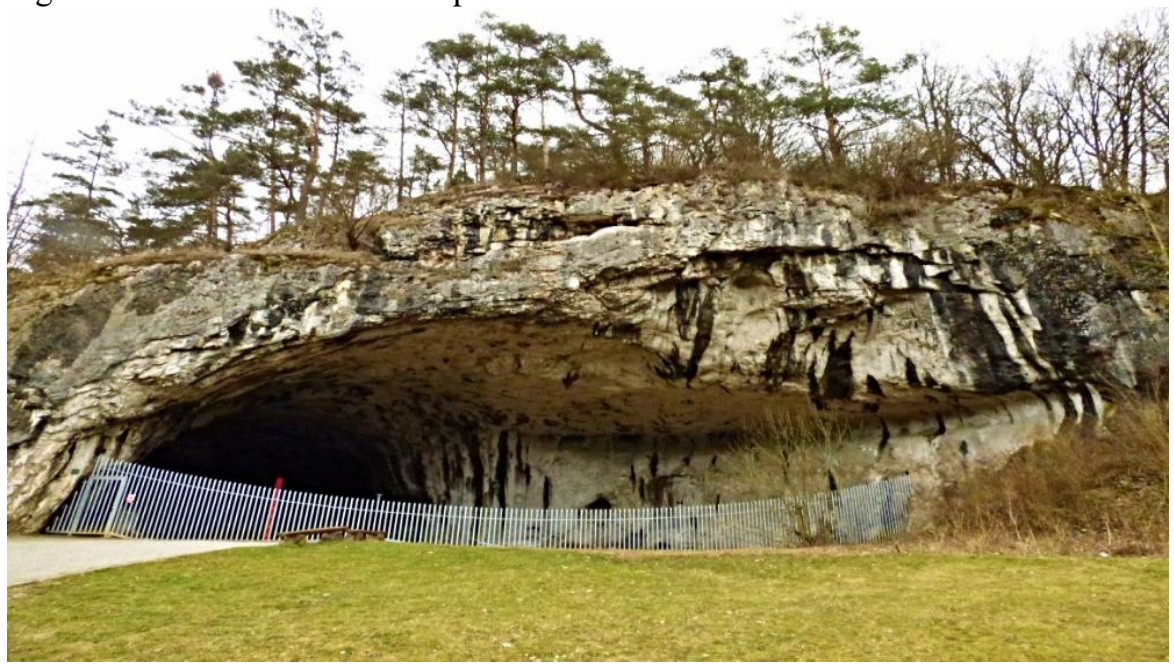

Zdroj: Foto Hübelová

Doba železná, 800 až 600 roků př. n. 1. byla dobou vzniku nejen základů trvalého osídlení ale pravděpodobně také počátkem železářské výroby. Za časově nejstarší fundace železných předmětů jsou považovány nálezy železářského nářadí a výrobků v jeskyni Býčí skála ze 4. až 3. stol. př. n. 1. (Golec, 2007). V roce 1872 byl Jindřichem Wankelem $\mathrm{v}$ jeskyni Býčí skála učiněn největší moravský halštatský nález, který obsahoval mnoho kosterních pozůstatků. Ještě před zahájením Wankelových výzkumů byla v jeskyni nalezena soška býčka ulitého z bronzu, který měl na čele kousek železa (Absolon, 1970a).

Výroba a používání železa ovlivnilo podstatné rozšíření rud tohoto kovu v Moravském krasu. K velkému rozvoji zpracování železa v Moravském krasu došlo v mladším halštatském období (těsně před první polovinou 1. tisíciletí př.n.1.). Př́mým dokladem vyspělé hutnické činnosti je nález kovářské dílny v jeskyni Býčí skála. V této dílně, patrně spěšně opuštěné, byly nalezeny obrovské perlíky, dláta, klíny, kovadlina, zlomky železa a části dvojhrotých hřiven. Kovářská dílna v Býčí skále je v historii železářství ojedinělým nálezem světového významu. Relativně př́znivé podmínky pro primitivní zemědělskou výrobu poskytovaly v době halštatské základní zdroj obživy (Kreps, 1976). 


\section{Středověk}

V období od pádu Západořímské říše až do objevení Ameriky se propojenost mezi př́rodním prostředím a společností vyvíjelo kvalitativně jinak než ve starověku. Slované přicházeli na Moravu asi od 5. stol. a pokračovali ve více než tisícileté tradici výroby. Pronikání slovanského obyvatelstva do těchto oblastí bylo tedy účelové a souviselo s hledáním železné rudy (Pleiner, 1958). Hutnické dílny z doby Velkomoravské říše (8. - 9. století n. 1.) využívaly železnou rudu střední části Moravského krasu (Chalupa, Láznička 1989). Železná ruda se nacházela v nejbližším okolí dnešních obcí Adamov, Olomučany nebo Rudice (Šimák, 1983). V období Velkomoravské říše (9. stol.) již probíhala vysoce organizovaná výroba v sériových pecích (Golec, 2014, s. 354). Na celé Moravě byly objeveny z této doby jen dvě hutě, které byly schopny vyrábět velké množství kvalitního železa (obr. 2) (Šimák, 1983).

Obr. 2: Výroba železa v seriových pecích

Figure 2: Iron production in series furnaces

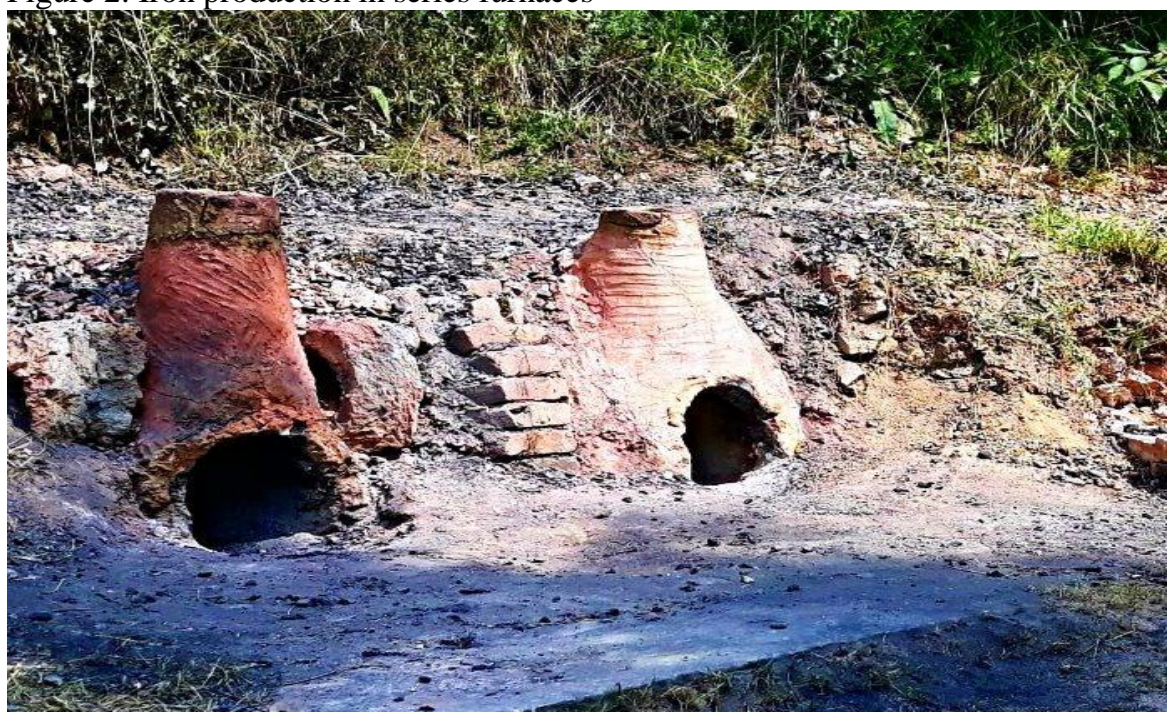

Zdroj: Foto Chalupa

V okolí dnešního Adamova byla nalezena železná struska společně se slovanskými střepy a zlomky nádob, které byly zařazeny do 11. stol. (Kreps, 1976). Obdobné nálezy byly zdokumentovány také v okolí obce Rudice (Hübelová, 2016).

Rozvoj hutnictví umožnil nejen růst počtu obyvatel a produktivity práce, ale i zvýšení jejich civilizační úrovně. V tomto období, které je spojené s růstem počtu 
obyvatel a zpracováním rud železa, se již mohl projevovat vliv lidské činnosti na kvalitu prostředí a vody. Hutní výrobou, těžbou rud a odvozem odpadního materiálu se objevily v krajině antropogenní formy reliéfu. Přeprava většího množství dřeva a rud si vyžádala úpravu komunikací. Obyvatelstvo nebylo výrobně vázáno $\mathrm{k}$ půdě, což umožnilo zaměstnání většího počtu pracovníků $\mathrm{v}$ řemeslné výrobě (Chalupová, 1997).

Železo se vyrábělo ve vybudovaných pecích šachtovitého tvaru, případně ve vhloubených jamách v terénu. Vlastníky půdy ve středověku byla vedle panovníka zejména šlechta. Na Blanensku vlastnila rozsáhlá území také církev. Kláštery dostávaly od panovníka obvykle lesnatou krajinu, kterou proměňovaly $\mathrm{v}$ úrodnou půdu a pastviny. Díky kolonizačním snahám šlechty se asi od 13. stol. začaly stavět kamenné hrady (Plaček, 2001). V oblasti Moravského krasu jsou to dnešní pozůstatky hradů Blansek, Ronov, Holštejn, Čertův hrádek a v té době politicky nejsilnějš́iho Nového hradu (Golec, 2014). Obchod a řemeslo se soustřed'ovalo ve městech a v menších městečkách, která dostávala významná privilegia. V době předhusitské to byly především obce Jedovnice a Holštejn (Chalupová, 1997).V období vrcholného středověku (12. až 15. stol.) došlo k vytvoření nové sítě vesnic (Štrof, 1987). Následně ale mnohé z nich opět zanikly (Černý, 1992).

Od 14. stol. došlo ke kvalitativní změně zpracování železné rudy. Železo se sice i nadále tavilo ve vybudovaných pecích šachtovitého tvaru, prrípadně ve vhloubených jamách $\mathrm{v}$ terénu, ale produkt pece se dále zpracovával do žádoucího tvaru hamerským kladivem, které bylo poháněno mechanickou energií pomocí vodního kola.

První hamry se v našich zemích objevily kolem 1. pol. 14. stol. (Kreps, 1976). Na rozdíl od předešlých období vyžadovala výroba železa v hamrech kromě základních materiálů - železné rudy a dřevěného uhlí - ještě dostačující zdroje vodní energie. Těžba rud byla soustředěna především do střední (obce Rudice a Olomučany) a severozápadní (obec Sloup) části Moravského krasu. Těžba probíhala formou povrchového sběru limonických železných rud nebo těžbou železné rudy v nehlubinných dolech (Bukhardt, 1977).

Historické názvy různých částí Moravského krasu (např. propadání Nová Rasovna a Stará Rasovna) také svědčí o záměrné likvidaci uhynulých zvířat do podzemních prostor místo jejich pracného zahrabání na mrchovištích. Tato místa byla vždy v okolí obce vyhrazena pro odstraňování uhynulých zvířat - nejčastěji $\mathrm{z}$ důvodů onemocnění - antrax, mor skotu, klasický mor prasat, slintavka a kulhavka přežvýkavců (Pavlík, 2014).

\section{Novověk}

$\mathrm{V}$ průběhu třicetileté války, která zasáhla také oblast Moravského krasu (1618 až 1648) a těsné po ní, se významně změnil charakter osídlení. Během války se dokonce v jeskyni Švédův stůl v údolí Řicčky utábořilo na čas švédské vojsko 
(Koudelka, 1889). Pavlík (2014) uvádí kromě přímých válečných útrap také zvýšené šíření nemocí lidí a zvířat, zejména tuberkulóza, tyfus a bubonický mor u lidí a mor skotu, slintavka a kulhavka přežvýkavců (Pavlík, 2014). V roce 1645 dobyli Švédové Nový hrad (Černý, 1992).

Obr. 3: Větrný mlýn Rudice

Figure 3: Windmill Rudice

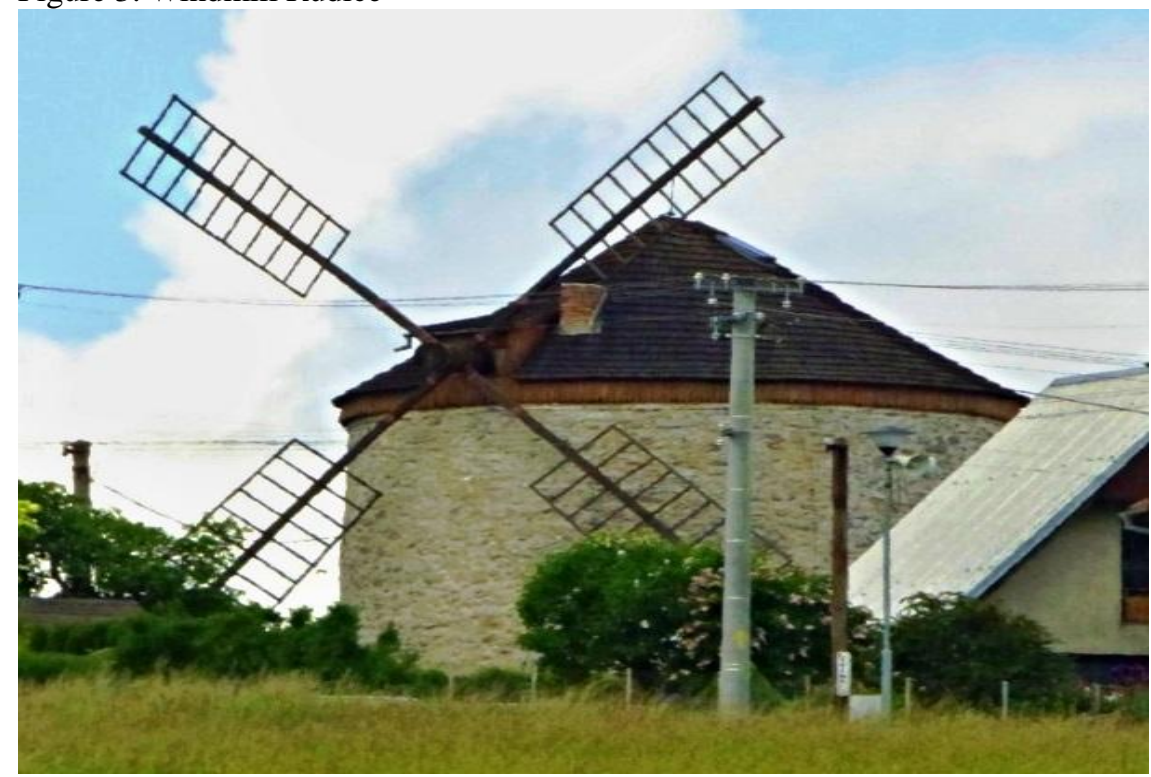

Zdroj: Foto Pavlík

Největší změna nastala $\mathrm{v}$ důsledku technického a technologického rozvoje a vlivem budoucích průmyslových revolucí. V období od 18.do 19.století se výrazně změnily hospodářské sektory $\mathrm{v}$ regionu Moravského krasu. Průběžně vývoj spěl ke vzniku manufakturní výroby a postupně $\mathrm{k}$ průmyslové velkovýrobě, která znamenala společenské, kulturní a politické změny. Současně s vývojem zemědělství se vyvíjela i průmyslová odvětví. To umožnilo výrobu prvních zemědělských strojů a nářadí, např. ruchadla, parního pluhu, žacího stroje a dalších (obr. 3).

První manufakturní hamry byly postaveny v roce 1698 (Chylík, 1948). Již od konce 16. stol. se objevovaly první dřevouhelné pece. Kvalitativně nový rozkvět železářství nastal za nových majitelů Salmů-Reifferscheidů, kteří koupili blanenské panství v roce 1766. Železná ruda se zpracovávala v nových hutích v Josefově u obce Adamov (Františkova hut' při Krrtinském potoce, která je zakreslena i v mapách z let 1764 - 1768), u Jedovnic (Salmova hut' při Jedovnickém potoce), v 
údolí řeky Punkvy (Starohraběcí, Mariánská a Kněžnina hut') a u řeky Svitavy (Paulinka a Klamova hut'). Většina z nich se dochovala do současnosti. Intenzívní hlubinná těžba železné rudy probíhala v oblasti obce Rudice od 2. pol. 18. stol. do roku 1893, kdy byly zásoby vyčerpány (obr. 4). Podstatným energetickým zdrojem a surovinou používanou $\mathrm{k}$ výrobě železa ve vysokých pecích bylo dřevěné uhlí, jež se vyrábělo v milíŕích. Industrializace a urbanizace vedly ke zvýšení koncentrace fosforečnanů, dusičnanů, síranů, organických látek, těžkých kovů i bakterií v podzemních vodách (Andreo et al., 2006). Původní lesní vegetace smíšených dřevin byla prakticky zničena a následně často nahrazena smrkovými monokulturami, které se ještě dnes vyskytují hlavně na severu krasové oblasti (obr.5). Spotřeba dřevěného uhlí i přes úsporná opatření byla značná a jeho nedostatek byl častou příčinou přerušení výrobního procesu ve vysokých pecích. Františkova hut' v Josefovském údolí pracovala až do roku 1877 (Kreps, 1976). Do 18. století byl region, kromě zpracování železné rudy, známý také jako středisko chovu ovcí (Kohn, 1977).

Je zajímavé, že jeskyně v určitých obdobích měly opět svoji původní sídelní roli. Jeskyně Pekárna a okolní jeskyně poskytly v průběhu francouzských válek (bitva u Slavkova roku 1805) útočiště všem mlynářům z okolí, kteří s sebou vzali veškerý majetek i dobytek (Ondrušková, 2011). Protože se lidé obávali rabování vojáků, zakopávali do jeskyní své poklady (v Pekárně oltářní kalichy). O podobném využití Pekárny máme zprávy ještě z válek rakousko-pruských z roku 1866 (Koudelka, 1889). Prostor mohl ale také poskytnout místo pro ustájení domácího dobytka na noc. Z písemných pramenů je známo využívání jeskyně Kravské nebo Býčí skály (Wankel, 1882, Wágner, 1959). Doklady podobného užití jeskyní můžeme objevit i v původech jejich názvů, např. Pastýřská a Kravská jeskyně, Ovčí díra (obr.6).

Zvyšuje se znečistování prostředí, zejména díky "odpadní kanalizaci", kterou představovalo splavování do jeskynních prostor. Nagel (1749) např. popisuje Sloupské jeskyně jako hluboký a zapáchající skalní labyrint. Koncem 18. stol. Mayer (1781) píše, že Sloupské jeskyně mu připadaly „nanejvýš obtižnými k prozkoumáni" a byly místem, kde se „nedá dýchat“. Wankel (1882) poznamenává, že "vzduch ve Sloupské jeskyni príšerně páchne, ale světla nezhasinaji". Křriž (1892) publikoval také, že zdroj zápachu způsobuje naplavené dřevo, jehličí a listí, které bylo smícháno s hlínou a pískem.

Z vývoje lze také vysledovat vliv historických událostí, jako byl pokles obyvatel v důsledku 1. světové války, hospodářské krize 30. let minulého století a ekonomických a společenských změn po roce 1989 (tab 1, 2) (Hübelová, 2014). Strmý nárůst počtu obyvatel je zaznamenaný v období let 2011 až 2015, ve kterém se silně projevuje vliv suburbanizace (Hübelová a kol., 2016).

Růst lidnatosti v časové řadě od roku 1869 je patrný téměř ve všech 22 vybraných obcí regionu MK, výjimku představují dvě obce s útlumem a zrušením hutní nebo sklářské výroby. 
Obr. 4: Slévárenské písky Rudice-Seč

Figure 4: Foundry sands Rudice-Seč

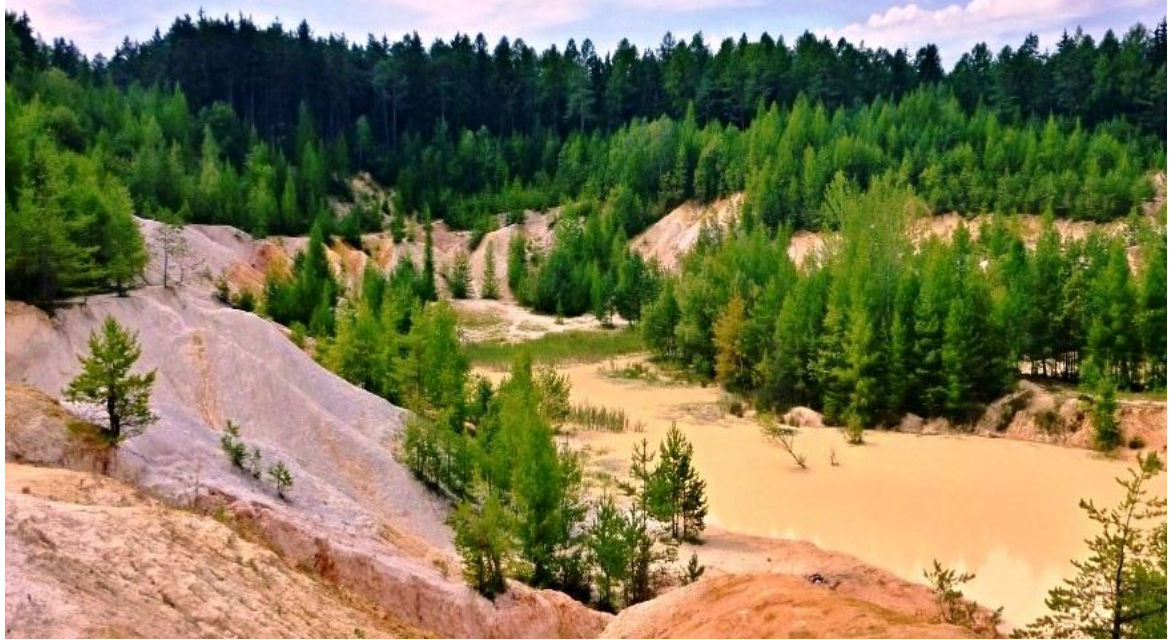

Zdroj: Foto Hübelová

Obr. 5: Kolíbky v Rudickém propadání

Figure 5: Cradles in Rudy's Fall

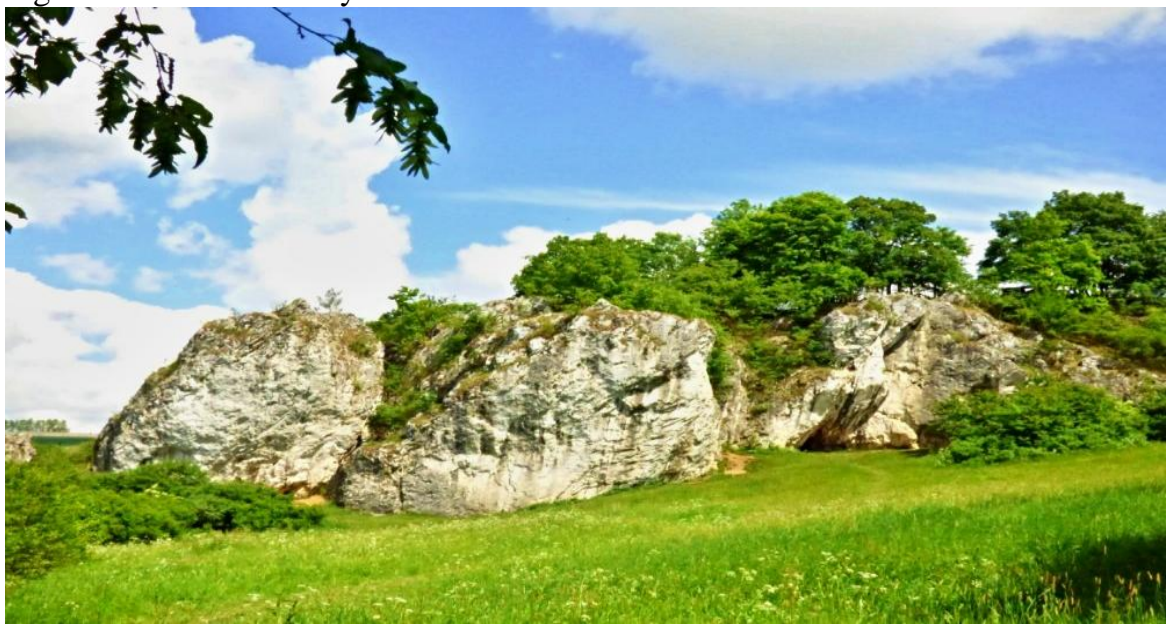

Zdroj: Foto Pavlík 
Obr. 6: Nová Rasovna

Figure 6: New Rasnov

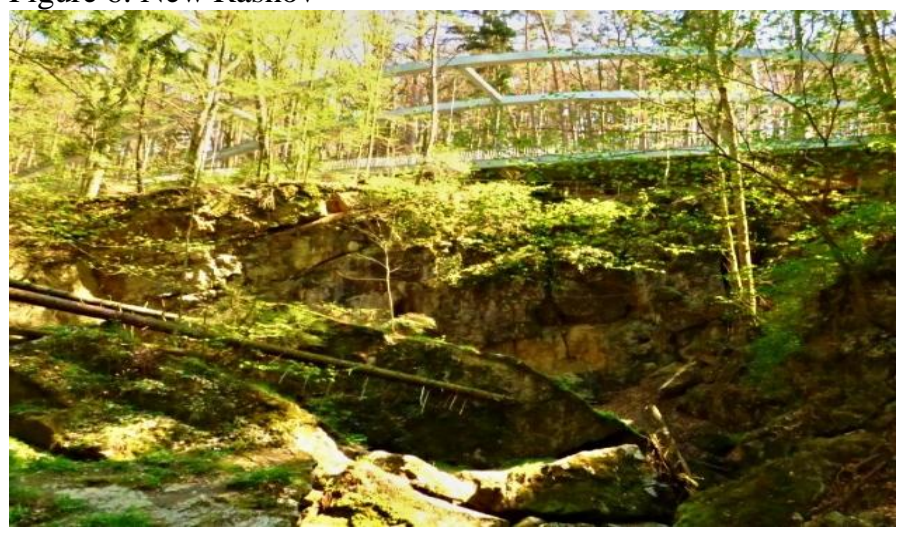

Zdroj: Foto Pavlík

Byly to obce Olomučany (blízkost hutní výroby a sklářská dílna) a Senetářov (perlet'ářství). Ostatní čtyři obce s populačním úbytkem se nachází v periferních částech regionu a mají špatnou dopravní dostupnost do blízkých měst: Bukovina, Holštejn, Vilémovice a Žd'ár (Hübelová a kol., 2016).

Tab.1: Vývoj počtu obyvatel ve 22 obcích regionu MK v letech 1869 až 2015

Table 1: Population development in 22 municipalities of the MK region between 1869 and 2015

\begin{tabular}{|l|r|r|r|r|r|r|r|r|}
\hline \multirow{2}{*}{\multicolumn{1}{|c|}{ Obec }} & \multicolumn{8}{|c|}{ Počet obyvatel } \\
\cline { 2 - 10 } & $\mathbf{1 8 6 9}$ & $\mathbf{1 8 8 0}$ & $\mathbf{1 8 9 0}$ & $\mathbf{1 9 0 0}$ & $\mathbf{1 9 1 0}$ & $\mathbf{1 9 2 1}$ & \multicolumn{1}{c|}{$\mathbf{1 9 3 0}$} & $\mathbf{1 9 5 0}$ \\
\hline Adamov & 902 & 953 & 728 & 792 & 816 & 998 & 1148 & 2090 \\
\hline Březina & 560 & 623 & 639 & 650 & 720 & 672 & 675 & 623 \\
\hline Bukovina & 423 & 422 & 439 & 457 & 490 & 455 & 393 & 333 \\
\hline Bukovinka & 373 & 405 & 449 & 407 & 422 & 430 & 387 & 423 \\
\hline Habrůvka & 483 & 486 & 592 & 618 & 600 & 549 & 575 & 709 \\
\hline Holštejn & 239 & 238 & 253 & 248 & 260 & 240 & 211 & 220 \\
\hline Hostěnice & 435 & 510 & 534 & 560 & 657 & 596 & 598 & 539 \\
\hline Jedovnice & 1540 & 1448 & 1483 & 1731 & 1933 & 1831 & 1742 & 1760 \\
\hline Kotvrdovice & 828 & 862 & 870 & 845 & 886 & 962 & 859 & 848 \\
\hline Krasová & 290 & 322 & 339 & 342 & 323 & 328 & 305 & 290 \\
\hline Křtiny & 612 & 571 & 558 & 547 & 530 & 504 & 513 & 649 \\
\hline Ochoz u Brna & 885 & 941 & 995 & 996 & 1054 & 998 & 987 & 1095 \\
\hline Olomučany & 1064 & 1150 & 1244 & 1425 & 1455 & 1439 & 1286 & 1155 \\
\hline
\end{tabular}




\begin{tabular}{|c|c|c|c|c|c|c|c|c|}
\hline Ostrov u Macochy & 1089 & 1210 & 1172 & 1140 & 1173 & 1234 & 1261 & 1261 \\
\hline Petrovice & 514 & 519 & 537 & 594 & 586 & 615 & 636 & 577 \\
\hline Rudice & 687 & 773 & 843 & 887 & 1001 & 1010 & 918 & 947 \\
\hline Senetářov & 725 & 721 & 747 & 747 & 746 & 711 & 661 & 584 \\
\hline Sloup & 539 & 425 & 436 & 467 & 636 & 579 & 595 & 610 \\
\hline Šošůvka & 477 & 649 & 713 & 703 & 732 & 728 & 680 & 628 \\
\hline Vavřinec & 537 & 635 & 698 & 768 & 761 & 770 & 729 & 690 \\
\hline Vilémovice & 532 & 582 & 576 & 565 & 659 & 616 & 610 & 542 \\
\hline Žd'ár & 532 & 541 & 539 & 626 & 609 & 574 & 552 & 439 \\
\hline$\Sigma$ & 14266 & 14986 & 15384 & 16115 & 17049 & 16839 & 16321 & 17012 \\
\hline \multirow{2}{*}{ Obec } & \multicolumn{8}{|c|}{ Počet obyvatel } \\
\hline & 1961 & 1970 & 1980 & 1991 & 2001 & 2011 & 2015 & - \\
\hline Adamov & 3139 & 3787 & 5088 & 5089 & 4970 & 4591 & 4549 & - \\
\hline Březina & 684 & 707 & 693 & 628 & 593 & 812 & 956 & - \\
\hline Bukovina & 330 & 323 & 332 & 322 & 322 & 353 & 371 & - \\
\hline Bukovinka & 446 & 442 & 391 & 355 & 304 & 476 & 517 & - \\
\hline Habrůvka & 464 & 446 & 370 & 346 & 335 & 388 & 411 & - \\
\hline Holštejn & 223 & 226 & 209 & 161 & 147 & 153 & 163 & - \\
\hline Hostěnice & 590 & 534 & 510 & 457 & 450 & 644 & 695 & - \\
\hline Jedovnice & 1857 & 1930 & 2177 & 2440 & 2487 & 2748 & 2763 & - \\
\hline Kotvrdovice & 911 & 890 & 858 & 866 & 838 & 862 & 900 & - \\
\hline Krasová & 325 & 329 & 293 & 257 & 248 & 291 & 348 & - \\
\hline Křtiny & 779 & 822 & 826 & 754 & 768 & 796 & 808 & - \\
\hline Ochoz u Brna & 1167 & 1196 & 1193 & 1058 & 1090 & 1265 & 1318 & - \\
\hline Olomučany & 1025 & 1015 & 941 & 882 & 890 & 946 & 1017 & - \\
\hline Ostrov u Macochy & 1277 & 1216 & 1173 & 1111 & 1086 & 1081 & 1112 & - \\
\hline Petrovice & 546 & 533 & 445 & 399 & 419 & 606 & 627 & - \\
\hline Rudice & 998 & 938 & 882 & 793 & 824 & 903 & 943 & - \\
\hline Senetářov & 617 & 598 & 542 & 524 & 493 & 510 & 536 & - \\
\hline Sloup & 676 & 751 & 913 & 931 & 891 & 931 & 947 & - \\
\hline Šošůvka & 682 & 697 & 700 & 694 & 711 & 670 & 690 & - \\
\hline Vavřinec & 644 & 657 & 685 & 621 & 645 & 648 & 866 & - \\
\hline Vilémovice & 525 & 461 & 388 & 302 & 303 & 283 & 328 & - \\
\hline Žd'ár & 422 & 415 & 398 & 363 & 359 & 365 & 390 & - \\
\hline$\Sigma$ & 18327 & 18913 & 20007 & 19353 & 19173 & 19241 & 21255 & - \\
\hline
\end{tabular}

Zdroj: Hübelová, Hořínek, Pavlík 2016b, data ČSÚ, 2016 
S vývojem lidnatosti ve shodném období koresponduje také vývoj počtu domů v obcích regionu Moravského krasu. Ve všech 22 obcích je v období let 1867 až 2015 zaznamenán růst počtu domů. Celkový počet domů se navýšil z 1778 $\mathrm{v}$ roce 1867 na $5280 \mathrm{v}$ roce 2015, což je na rozdíl od třetinového přírůstku obyvatel téměř trojnásobné zvýšení.

Tab. 2: Vývoj počtu domů ve 22 obcích regionu MK v letech 1869 až 2015

Table 2: Development of the number of houses in 22 villages in the region MK in the years $1869-2015$

\begin{tabular}{|c|c|c|c|c|c|c|c|}
\hline \multirow{2}{*}{ Obec } & \multicolumn{7}{|c|}{ Počet domů } \\
\hline & 1869 & 1880 & 1890 & 1900 & 1910 & 1921 & 1930 \\
\hline Adamov & 80 & 80 & 78 & 82 & 100 & 113 & 157 \\
\hline Březina & 64 & 72 & 79 & 87 & 110 & 119 & 136 \\
\hline Bukovina & 50 & 60 & 66 & 66 & 78 & 80 & 89 \\
\hline Bukovinka & 66 & 66 & 73 & 87 & 97 & 100 & 116 \\
\hline Habrůvka & 37 & 38 & 37 & 38 & 38 & 38 & 39 \\
\hline Holštejn & 194 & 201 & 207 & 224 & 258 & 265 & 300 \\
\hline Hostěnice & 120 & 125 & 131 & 138 & 150 & 152 & 174 \\
\hline Jedovnice & 38 & 38 & 42 & 44 & 47 & 48 & 51 \\
\hline Kotvrdovice & 70 & 80 & 88 & 90 & 99 & 106 & 112 \\
\hline Krasová & 138 & 150 & 150 & 168 & 178 & 178 & 211 \\
\hline Křtiny & 153 & 169 & 183 & 194 & 212 & 216 & 244 \\
\hline Ochoz u Brna & 60 & 66 & 72 & 82 & 97 & 104 & 119 \\
\hline Olomučany & 91 & 106 & 114 & 127 & 138 & 145 & 167 \\
\hline Ostrov u Macochy & 94 & 96 & 107 & 115 & 122 & 123 & 126 \\
\hline Petrovice & 75 & 57 & 56 & 69 & 82 & 84 & 97 \\
\hline Rudice & 65 & 99 & 106 & 115 & 121 & 121 & 132 \\
\hline Senetářov & 27 & 29 & 31 & 33 & 33 & 35 & 48 \\
\hline Sloup & 52 & 55 & 59 & 62 & 66 & 66 & 76 \\
\hline Šošůvka & 34 & 39 & 45 & 45 & 53 & 53 & 52 \\
\hline Vavřinec & 86 & 94 & 104 & 107 & 119 & 119 & 128 \\
\hline Vilémovice & 68 & 85 & 91 & 102 & 117 & 121 & 132 \\
\hline Žd’ár & 116 & 121 & 130 & 145 & 161 & 164 & 213 \\
\hline$\Sigma$ & 1778 & 1926 & 2049 & 2220 & 2476 & 2550 & 2919 \\
\hline \multirow{2}{*}{ Obec } & \multicolumn{7}{|c|}{ Počet domů } \\
\hline & 1950 & 1961 & 1970 & 1980 & 1991 & 2001 & 2011 \\
\hline Adamov & 236 & 268 & 262 & 281 & 301 & 295 & 318 \\
\hline
\end{tabular}




\begin{tabular}{|l|r|r|r|r|r|r|r|}
\hline Březina & 154 & 158 & 167 & 151 & 166 & 180 & 188 \\
\hline Bukovina & 111 & 112 & 116 & 113 & 127 & 134 & 192 \\
\hline Bukovinka & 117 & 108 & 111 & 113 & 122 & 129 & 157 \\
\hline Habrůvka & 51 & 52 & 56 & 53 & 59 & 60 & 73 \\
\hline Holštejn & 421 & 440 & 465 & 494 & 581 & 616 & 680 \\
\hline Hostěnice & 196 & 209 & 211 & 216 & 255 & 265 & 282 \\
\hline Jedovnice & 72 & 75 & 80 & 74 & 86 & 88 & 103 \\
\hline Kotvrdovice & 136 & 167 & 171 & 205 & 215 & 225 & 239 \\
\hline Krasová & 263 & 258 & 267 & 264 & 305 & 327 & 338 \\
\hline Křtiny & 298 & 319 & 320 & 311 & 386 & 396 & 427 \\
\hline Ochoz u Brna & 132 & 131 & 136 & 126 & 146 & 154 & 174 \\
\hline Olomučany & 203 & 226 & 233 & 237 & 235 & 290 & 320 \\
\hline Ostrov u Macochy & 131 & 131 & 133 & 130 & 147 & 154 & 168 \\
\hline Petrovice & 114 & 138 & 152 & 167 & 195 & 208 & 227 \\
\hline Rudice & 140 & 148 & 162 & 166 & 204 & 210 & 217 \\
\hline Senetáŕov & 53 &. & 53 & 51 & 56 & 66 & 72 \\
\hline Sloup & 87 & 212 & 90 & 110 & 122 & 132 & 138 \\
\hline Šošůvka & 63 &. & 65 & 69 & 70 & 87 & 88 \\
\hline Vav̌rinec & 150 & 212 & 155 & 179 & 192 & 219 & 226 \\
\hline Vilémovice & 145 & 148 & 149 & 153 & 176 & 182 & 236 \\
\hline Žd'ár & 325 & 282 & 305 & 314 & 353 & 388 & 417 \\
\hline$\Sigma$ & 3598 & 3794 & 3859 & 3977 & 4499 & 4805 & 5280 \\
\hline Zdroj: & & & & & & \\
\hline
\end{tabular}

Zdroj: Hübelová, Hořínek, Pavlík 2016b, data ČSÚ, 2016

Tento dlouhodobý trend ukazuje sice na růst počtu domácností, ale současně na snižující se průměrnou velikost domácností. Lze usuzovat, že s růstem počtu obyvatel a domů rostou nejen nároky na množství pitné vody, ale také na zpracování vody odpadní. Zvětšování zastavěné plochy vede ke snižování ekologické stability krajiny a kvality vody a může mít důsledky pro život obyvatel i návštěvníků MK (Hübelová, Pavlík, 2016). Do poloviny minulého století bylo možné považovat zemědělskou výrobu a vznikající agroekosystémy za relativně stabilní, schopné autoregulace a zajištění ekologicky vyvážené krajiny. Začátkem 60. let 20. stol. byla intenzifikace natolik výrazná (rozorávání závrtů, scelování pozemků vedoucí k erozi do závrtů apod.), že již ovlivnila kvalitu povrchové i pozemní krasové vody a krasových jevů. Pěstovaly se plodiny náročné na živiny, zemědělská půda $\mathrm{v}$ krasu byla vydatně hnojena průmyslovými hnojivy a ve skapových vodách pronikaly do jeskyní zejména dusičnany a chloridy. Zvýšení obsahu dusičnanů ve skapech pod zemědělskými pozemky se ukazuje až 
desetinásobné a chloridů až trojnásobné v porovnání se skapy pod lesem (Boyer, Pasquarell, 1996).

V současné době jsou využívána tekutá průmyslová hnojiva, organické hnojení, upravily se osevní postupy a na plochách s významným výskytem závrtů došlo k zatravnění. Je možno říci, že těžba surovin neodmyslitelně patří neoddělitelně $\mathrm{k}$ historii i současnosti Moravského krasu, která ovlivnila krajinu zejména ve střední části krasu v oblasti Rudické a Babické plošiny. Kromě železné rudy byl a stále je významnou nerostnou surovinou Moravského krasu vápenec. Během Druhé světové války se objevilo další zcela netypické využití jeskynních prostor, a to budování podzemních výrobních továren pro válečné účely, utajených pro leteckou špionáž a následné bombardování (jeskyně Kůlna a Michalka v severní části Moravského krasu. Jedná se o jeskyně Býčí skála, Výpustek, Mariánská a Drátenická ve střední části Moravského krasu (Absolon, 1970a, 1970b).

V poválečné historii shledáváme další zajímavé osudy jeskyní Moravského krasu. Poničená jeskyně Výpustek byla využita armádou jako protiatomový kryt $\mathrm{s}$ velitelským stanovištěm armády na Moravě. Armádou byla opuštěna až v roce 2001. V současné době je jeskyně Výpustek celoročně př́istupná veřejnosti. V jeskyni Michalce pak byly prostory bývalé továrny využity jako místo skladování a dozrávání sýru Niva, a to až do roku 2003. Kromě turistických účelů se v jeskyních prostorách objevují společenské aktivity jako koncerty pro výbornou akustiku, svatby, catering firem apod. Známé jsou také léčebné účinky $\mathrm{v}$ podobě speleoterapie v Císařské jeskyni u obce Ostrov u Macochy.

\section{Závěr}

Region Moravského krasu - kromě ojedinělé bioty s četnými relikty a endemity, s pěti prístupnými jeskyněmi a zajímavými povrchovými útvary (škrapy, závrty, polje, propadání, vyvěračky) a podzemními krasovými jevy (jeskyně s krápníkovou výzdobou) - disponuje také specifickým historickým vývojem.

Je průkazné, že lidská činnost zde byla vždy úzce provázána s unikátním prrírodním prostředím a krajinou. Jeskyně od pravěku poskytovaly útočiště a staly se součástí sídelní struktury. Svoji roli hráli ve středověku i novověku a nabízely prostor pro úkryt $\mathrm{v}$ době válek, řemeslnou a válečnou výrobu, ustájení dobytka apod. Také v dnešní době slouží řadě účelů. Existence člověka v krasu v minulosti i současnosti se neváže pouze k jeskyním. Nerostné suroviny, dostatek dřevní hmoty a vodní energie Moravského krasu se staly základem pro rozvoj hutnictví, železářství a později transformovaného strojírenského průmyslu celého regionu.

Rostoucí lidnatost znamenala rozšiřrování sídel a intenzifikaci zemědělství, což vede ke zvyšování zátěže pro krajinu, kvalitu vodního prostředí i ekologickou stabilitu (Hübelová, Pavlík, 2016, Pavlík a kol., 2016). 
Archeologické a paleontologické nálezy v jeskyních, kulturní památky a antropogenní změny $v$ krajině lze pozorovat a navštívit iv současné době a představují jeden z potenciálů cestovního ruchu regionu.

Lidská činnost, růst populace i osídlení sebou však nesou nebezpečí znehodnocení přírodního a především vodního prostředí, které hraje významnou roli jak při utváření krasu, tak při volnočasových pobytových aktivitách.

Studium a poznání symbiotických vazeb mezi př́rodní sférou, humánní sférou a historickým vývojem by se měly stát jedním z hlavních motivů návštěvy Moravského krasu.

\section{Literatura}

ABSOLON, K. 1970a. Moravský kras 1. Praha: Academia, 1970.

ABSOLON, K. 1970b. Moravský kras 2. Praha: Academia, 1970.

ANDREO, B. et al. 2006. Karst groundwater protection: First application of a PanEuropean Approach to vulnerability, hazard and risk mapping in the Sierra de Líbar (Southern Spain). In Science of the Total Environment. ISSN 0048-9697, 2006, vol. 357, no. 1-3, pp. 54-73.

ČERNÝ, E. 1992. Výsledky výzkumu zaniklých středověkých osad a jejich plužin. Brno: Muzejní vlastivědná společnost, 1992.

BOYER, D. G. - PASQUARELL, G. C. 1996. Agricultural land use effects on nitrate concentrations in a mature karst aquifer. In Water Resources Bulletin. ISSN 0043-1370, 1996, vol. 32, no. 7., pp. 565-573.

GOLEC, M. 2007. Cesta do podsvětí: Býčí skála. In Živá archeologie. ISSN 12131628,2007 , roč. 8 , s. 39-44.

HÜBELOVÁ, D. - PAVLÍK, I. 2016a. Vybraná rizika znehodnocení krasového prostředí lidskou činností na př́kladu CHKO Moravský kras. In 11 . mezinárodni konference Aktuální problémy cestovního ruchu. Jihlava: Vysoká škola polytechnická, 2016.

HÜBELOVÁ, D. - HOŘÍNEK, M. - PAVLÍK, I. 2016b. Dynamika obyvatelstva v letech 2001-2015 a úroveň technické infrastruktury obcí střední části Moravského krasu s ohledem na rizika kontaminace povrchové vody komunálním odpadem. In Region v rozvoji společnosti. Brno: Mendelova univerzita, 2016.

CHALUPA, P. - LÁZNIČKA, J. 1989. Geografická charakteristika, stav a perspektivy rozvoje životního prostředi okresu Blansko. OPS, ONV Blansko 1989. $101 \mathrm{~s}$.

CHALUPOVÁ, D. 1997. Průmyslová výroba na Blanensku. Diplomová práce. Brno: Pedagogická fakulta, Katedra geografie, 1997.

CHILÍK, J. 1948. Přehled dějin moravského průmyslu I. Brno: Matice Moravská. IVANIČKA, K. 1971. Úvod do ekonomickogeografického výzkumu. Bratislava: SAV, 1971. 
JACUNSKIJ, V. K. 1957. Historická geografie jako vědní obor. Praha, 1957.

KOUDELKA, F. 1889. Ze zapomenutého kraje Moravy. Jeskyně údolí Hádeckého. Brno, 1889.

KREPS, M. 1976. Dějiny adamovských strojíren a železáren do roku 1905. Brno: Blok, 1976.

MAYER, J. 1781. Versuch einer Beschreibung der Gegend um Sluppe in Mähren. In Schriften d. Berlinischen Ges. naturf. Freunde, Bd. II. Berlin, pp. 56-65.

NAGEL, J. A. 1749. Beschreibung deren auf Allerhöchsten Befehl Ihrer Röm. Kaas und Königl. Maytt. Francisci I. untersuchten in dem Hertzogthum Crain befindlichen Seltenheiten der Natur. 97 listů Fol., 25 tab. Tušových kreseb. Rukopis v dvorní knihovně vídeňské. MZK Rp-1.011.965, 1749.

ONDRUŠKOVÁ, S. 2011. Pravěk Moravského krasu (neolit - doba stěhování národi̊). Brno, 2011.

PAVLÍK, I. 2014. Rozvoj zdravého regionu. Význam infekčních onemocnění lidí a zviŕat a zoonóz při rozvoji regionů. Brno: Mendelova univerzita v Brně, 2014.

PAVLÍK, I. - KONEČNÝ, O. - HÜBELOVÁ, D., 2016. Povrchové a krasové vody v CHKO Moravský kras. In Studia Turistica. Jihlava, 2016 (v tisku).

ŠIMÁK, B. a kol. 1983. Vlastivédná mapa okresu Blansko a doprovodný text $k$ mapě (část obyvatelstvo a sídla). Praha: Kartografie, 1983.

WÁGNER, J. 1959. Z pověstí adamovských lesů. VZA III/3, 1959. Dostupné na internete: http://old.ochranaprirody.cz/res/data/181/023333.gif

\section{LINK OF THE NATURAL AND HUMAN COMPONENTS OF THE GEOSPHERE IN HISTORICAL DEVELOPMENT AS A MOTIVATION FOR THE VISIT OF MORAVIAN KARST}

\section{Summary}

The region of Moravian Karst, with the exception of specific biotopes with numerous relics and endemites, with five accessible caves and interesting surfaces and underground karst phenomena has also a specific historical development. Human activity here has always been closely linked to the unique natural environment and landscape. The prehistoric caves provided shelter and became part of the settlement structure. They played their part in the Middle Ages and the Modern Age and offered room for shelter during wars, craft and war production, cattle housing, etc. Today also serves a number of purposes, but the existence of man in the past in the past and present is not only connected to the caves. Mineral raw materials, sufficient wood mass and water power of the Moravian Karst became the basis for the development of metallurgy, ironmongery and the later transformed engineering industry of the whole region. Studying and understanding symbiotic links between the natural sphere, the human sphere, and the historical development should become one of the main miracles of the visit. 
Prof. PhDr. Petr Chalupa, CSc.

Katedra cestovního ruchu

Vysoká škola polytechnická Jihlava

Tolstého 16, 58601 Jihlava, Česká republika

E-mail: chalupapet@ seznam.cz

RNDr. PaedDr. Ján Veselovský, PhD.

Katedra cestovného ruchu

Fakulta stredoeurópskych štúdií

Univerzita Konštantína Filozofa v Nitre

Dražovská 4, 94974 Nitra, Slovenská republika

E-mail: jveselovský@ukf.sk 